\title{
Carotenoids Extracted from Promising Clones of Criolla Potato (Solanum tuberosum Group Phureja) for Food Industry
}

\author{
Leyton-Forero, G. '; R. Abdo2; L. Prieto3; J.C. Poveda-Pisco4; \\ M.S. Ceron-Lasso ${ }^{5}$
}

\section{Summary}

The carotenoids are natural pigments that contribute to the replacement of the synthetic colorants which are still used in food industry. With this aim, the carotenoids from 15 promising clones and one commercial variety, named Yema de Huevo, of Criolla potato (Solanum tuberosum Group Phureja) supplied by Corpoica were extracted and evaluated. The tubers lyophilized for $72 \mathrm{~h}$ by triplicate, and their carotenoids extracted with acetone and hexane. Absorbance of the supernatants obtained after centrifuging measured using spectrophotometry at intervals of $3 \mathrm{~nm}$. Presence of carotenoids was also confirmed by thin layer chromatography. Absorbance values showed a presence of lutein-5, 6-epoxide in clones $2,4,5,6,7,8,15$, and $\alpha$ carotene in clones $3,10,11,12,13,14,16,17$, and commercial variety. The promising clones 11,12 and 14 were selected due to their higher carotenoid concentration. Their carotenoids extracted were evaluated their stability under different $\mathrm{pH}$, temperature, and light conditions. A decrease in the color intensity was observed at $\mathbf{1 3 . 5}$ and $\mathbf{1 . 0}$ $\mathrm{pH}$. There were not significant changes of color intensity at 50 and $70{ }^{\circ} \mathrm{C}$ temperatures. This carotenoids exposure to the light displayed a decrease in the absorbance. After, a commercial colorless yogurt was dyed with the selected carotenoids. Carotenoids from promising clone 14 showed higher pigmentation according to the spatial coordinates CIELAB of $L^{*} 48.66 a^{\star}-1.65 b * 5.63$.

${ }_{1}^{1}$ Food Engineer, Universidad de La Salle, Bogota-Colombia, gleyton01@unisalle.edu.co

${ }^{2}$ Food Engineer, Technion - Israel Institute of Technology, Technion City, Haifa-Israel

${ }^{3}$ Researcher of Food Engineering Program, Universidad de La Salle, Bogota-Colombia

${ }^{4}$ Basic Sciences Department, Universidad de La Salle, Bogota-Colombia,

${ }^{5}$ Vegetable Agronomic Development and Research, Corpoica, Tibaitata-Colombia 
Additional key words:

Solid-liquid extraction, pigments, spectrophotometric analysis, spectral curves.

Accepted for publication: August 15, 2013.

Carotenoides extraídos de clones prometedores de papa "Criolla" (Solanum tuberosum Grupo Phureja) para su uso en la industria de alimentos

\section{Resumen}

Los carotenoides son pigmentos naturales que contribuyen al reemplazo de los colorantes sintéticos que se emplean aún en la industria de alimentos. Con ese propósito, los carotenoides de 15 clones promisorios y de la variedad comercial Yema de Huevo de papa Criolla (Solanum tuberosum Grupo Phureja), suministrados por CORPOICA, fueron extraídos y evaluados. Los tubérculos se liofilizaron durante $72 \mathrm{~h}$ por triplicado y sus carotenoides se extrajeron con acetona y hexano. La absorbancia de los sobrenadantes de los centrifugados se midió por espectrofotometría en intervalos de $3 \mathrm{~nm}$. La presencia de los carotenoides se confirmó también por cromatografía de capa fina. Las lecturas de absorbancia mostraron presencia de luteína-5,6-epóxido en los clones $2,4,5,6,7,8$ y 15; y $\alpha$ caroteno en los clones $3,10,11,12,13,14,16,17$ y la variedad comercial. Los clones promisorios 11, 12 y 14 fueron seleccionados por contener mayor concentración de carotenoides; a sus carotenoides extraídos se les evaluó la estabilidad en diferentes condiciones de $\mathrm{pH}$, temperatura y luz. En la intensidad del color se observó una disminución en $\mathrm{pH}$ de 13,5 y 1,0. No hubo cambios significativos en la intensidad del color en temperaturas de 50 y $70{ }^{\circ} \mathrm{C}$. Estos carotenoides expuestos a la luz presentaron una disminución en la absorbancia. Después a un yogur comercial sin color se le hizo una pigmentación con los carotenoides seleccionados. Los carotenoides del clon promisorio 14 mostraron más coloración según las 


\title{
coordenadas espaciales de CIELAB de $L^{*} 48,66 a^{*}-1,65$ b`5,63.
}

Palabras claves adicionales:

\author{
Extracción sólido-líquido, \\ pigmentos, análisis \\ espectrofotométrico, curvas \\ espectrales
}

\section{Introduction}

The use of synthetic colorants in food processing is becoming more restricted due to new regulatory policy addressed to issues of toxicity, allergic reactions, and intolerance of the synthetic colorants (Santos-Soriano et al., 2007). Rodriguez (2001) argued recently that food processors and technologists have shown great interest in the isolation, identification and purification of natural pigments, including carotenoids, owing to their nutritional value, colorant capacity, as well as their potential benefits to human health.

Carotenoids or tetraterpenoids are terpenoid pigments of 40 carbon chains obtained biosynthetically from geranil and geranil pyrophosphate. The majority of carotenoids are soluble in nonpolar solvents, and present colorations between yellow ( $\beta$ carotene) and red (lycopene). Olmedilla, Granado and Blanco (2001) stated about there are 40 to 50 carotenoid types available in foods which can be absorbed, and metabolized by the human body.

On the other hand, Criolla potato (Solanum tuberosum Group Phureja) is a native potato which is harvested in Andean Zone of Colombia. It has high nutritional value due to its vitamin, mineral, protein, and tuber flesh pigment content (ICBF, 2012). Many researches with Criolla potato have been undertaken to address the development of promising clones with potential for the export market, including good processing quality (Ceron et al., 2010). 
Burgos et al. (2009) emphasized the presence of carotenoids like zeaxanthin (orange color) and lutein (yellow color) in significant amounts in Criolla potato. Also, they reported levels of $2,000 \mu \mathrm{g} / 100 \mathrm{~g}$ of zeaxanthin in Solanum phureja. However, the carotenoid content displayed variation with the crop, variety, and clone.

CORPOICA and Universidad de La Salle have undertaken collaborative studies on the agronomical characteristics of promising clones and their physicochemical composition for industrial utilization in the future. As a component of this research, the carotenoid content in promising clones of native Criolla potatoes (Solanum tuberosum Group Phureja) was extracted and evaluated in order to benefit food production industries from their natural pigmentation.

\section{Materials and methods}

Materials. The Potato Improvement Program of CORPOICA provided 15 promising clones and one commercial variety named Yema de Huevo of Criolla potato harvested in El Rosal Town (2685 masl, $13^{\circ} \mathrm{C}$, north latitude $4^{\circ} 51^{\prime} 16^{\prime \prime}$, west longitude 74¹5'39", Departamento de Cundinamarca, Colombia). The clones were processed in the Fruit and Vegetable Pilot Plant at Universidad de La Salle, Bogota, Colombia. Since Criolla potatoes have a short life cycle (Corzo et al., 2003), and carotenoids are susceptible to degradation by oxygen, heat and light (Martinez, 2003), it was necessary to ensure the stability of the compound by a modified methodology using lyophilisation of tubers (Martinez, 2003).

Conditioning of material. First, tubers were cooled down to 4 ${ }^{\circ} \mathrm{C}$ in order to cut down respiration (Muñoz-Delgado, 1985). On the following day, the tubers were chopped in Javar ${ }^{\circledR}$ processor, and $100 \mathrm{~g} /$ clone was placed for $3 \mathrm{~h}$ in a Petri dish, and then frozen by VR Ingenieria ${ }^{\circledR}$ freezing tunnel with air velocity of $1.050 \mathrm{~m} / \mathrm{s}$ and temperature of $-23^{\circ} \mathrm{C}$, monitored by PCIM 7.2® software, to reach $-18{ }^{\circ} \mathrm{C}$. Frozen samples were transferred to Labconco® Model 7752000 lyophilizer for $72 \mathrm{~h}$ to 
remove moisture. Afterwards, the lyophilized clones were wrapped with aluminum-packaging and stored in the dark.

Carotenoid extraction. Carotenoids were extracted from lyophilized triplicate samples by acetone and hexane according to Biswas et al. (2011) methodology reported, i.e. hydrophilic and lipophilic pigments were extracted with acetone, and separation of lipophilic carotenoids was with a non-polar solvent like hexane by chemical selection (Rodriguez-Amaya and Kimura, 2004). Once extracted, carotenoids solutions of 15 promising clones and one commercial variety of Criolla potato were identified by Thermospectronic ${ }^{\circledR}$ Genesys 10 UV spectrophotometer with $3 \mathrm{~nm}$ intervals. In addition, the carotenoid type was identified by Thin Layer chromatography (TLC) carried out according to the methodology of RodriguezAmaya and Kimura (2004).

Stability and utilization of carotenoids. For further study, 3 out of 16 different tubers with higher levels of extracted carotenoides obtained, and their stability was tested different temperature, light and $\mathrm{pH}$ conditions through determination of absorbance following Melendez-Martinez et al. (2004). In order to verify the activity of selected carotenoid extractions, as well as their pigment appearance, were added to commercial colorless and tasteless yogurt for color determination in CIELAB spatial coordinates using a Konica Minolta ${ }^{\circledR}$ CR-400 colorimeter.

Statistical evaluation. The experimental results of the promising clones and with the commercial variety of Criolla potatoes were statistically analyzed using descriptive statistics and analysis of variance (ANOVA) of one-way randomized $(p<0.05)$, through the Statistix ${ }^{\circledR}$ version 9 software. Significant differences were analyzed by multiple comparison of Tukey test $(p<0.05)$.

\section{Results and discussion}


Promising clones. The tubers displayed yellow, purple, reddish and completely dark skin color. Tuber flesh color was yellow, purple or reddish with scattered spots and vascular ring in some clones. The promising clones and the commercial variety of Criolla potatoes were spherical, compressed, ovoid, and oblong in shape. Between 55 to $63 \%$ moisture was removed from the tubers by lyophilisation.

Extracted carotenoids. Carotenoids kept in dark without moisture and covered with aluminum-packaging, as recommended by Galicia (2009) and Martinez (2003), in order to prevent isomerisation by photo-oxidation. However, the original carotenoid color, after extraction, was degraded to opaque tonalities characterizing photo-oxidation. Hence, the oxidation reaction caused a decrease in the content of extracted carotenoids.

Figure 1 shows a characteristic curve of spectrophotometric analysis for carotenoids displaying three peaks. The central spectral peak shows the highest absorbance $\left(\lambda_{\max }\right)$ for a given wavelength. The spectral peaks obtained were compared with the data of absorbance-wavelength reported by Britton et al. (2004) and Davies (1976) for the identification of the specific carotenoid. This comparison lead to the conclusion that clones of Figure 1 (A) contained lutein-5, 6-epoxide, and clones with commercial variety of Figure 1 (B) contained a-carotene. In addition, the different solutions of extracted carotenoids showed similar spectral peaks (Figure 1), namely: 2, 4, 5, 6, 7, 8 and 15 clones for $\lambda_{\max }$ of $442 \mathrm{~nm}$, and 3,10,11, 12, 13, 14, 17 clones and commercial variety for $\lambda_{\max }$ of $448 \mathrm{~nm}$. 
Figure 1A. Spectral curves of extracted carotenoids from promising clones of Criolla potato at $\lambda_{\max }$ of $442 \mathrm{~nm}$

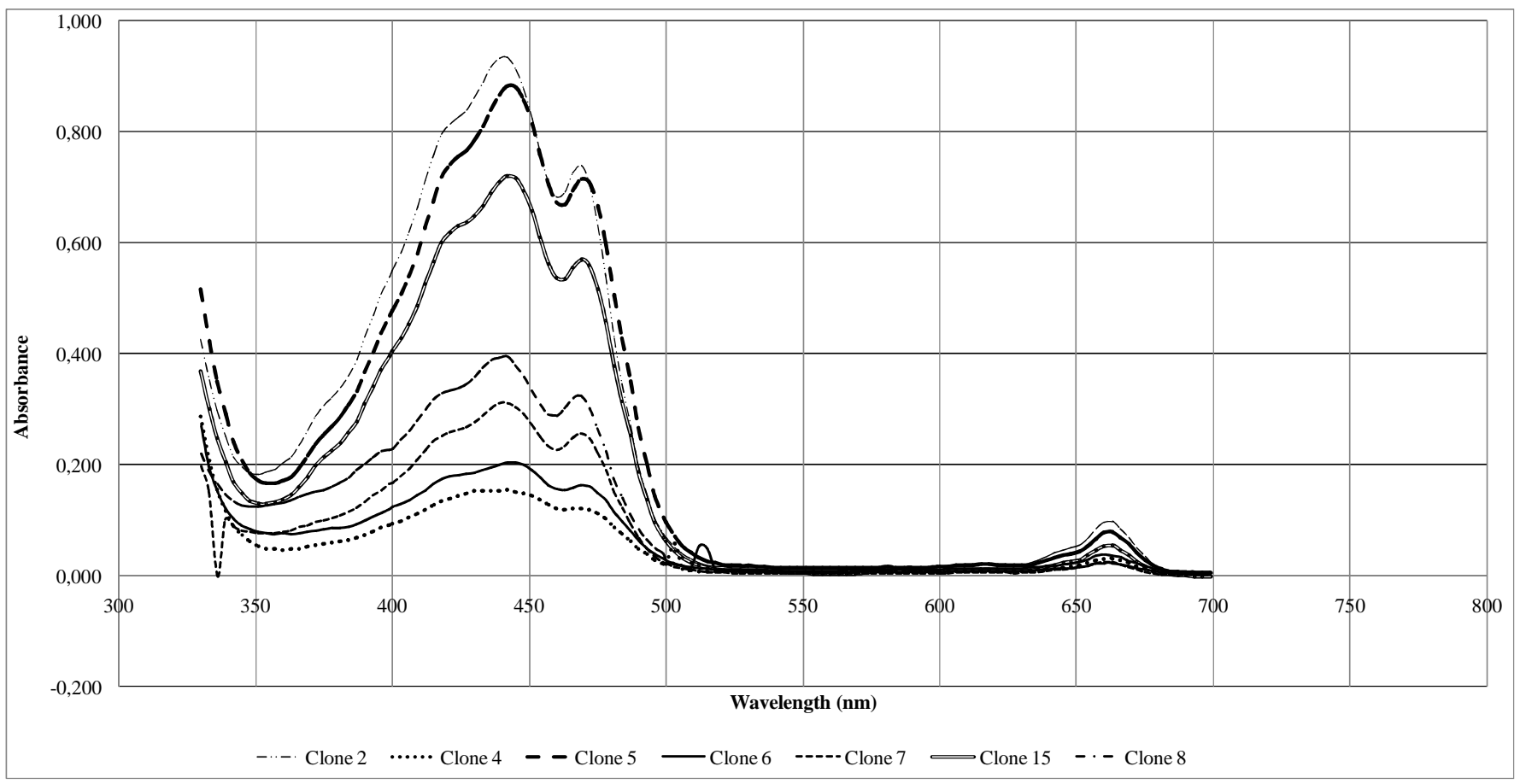


Figure 1B. Spectral curves of extracted carotenoids from promising clones of Criolla potato at $\lambda_{\max }$ of $448 \mathrm{~nm}$

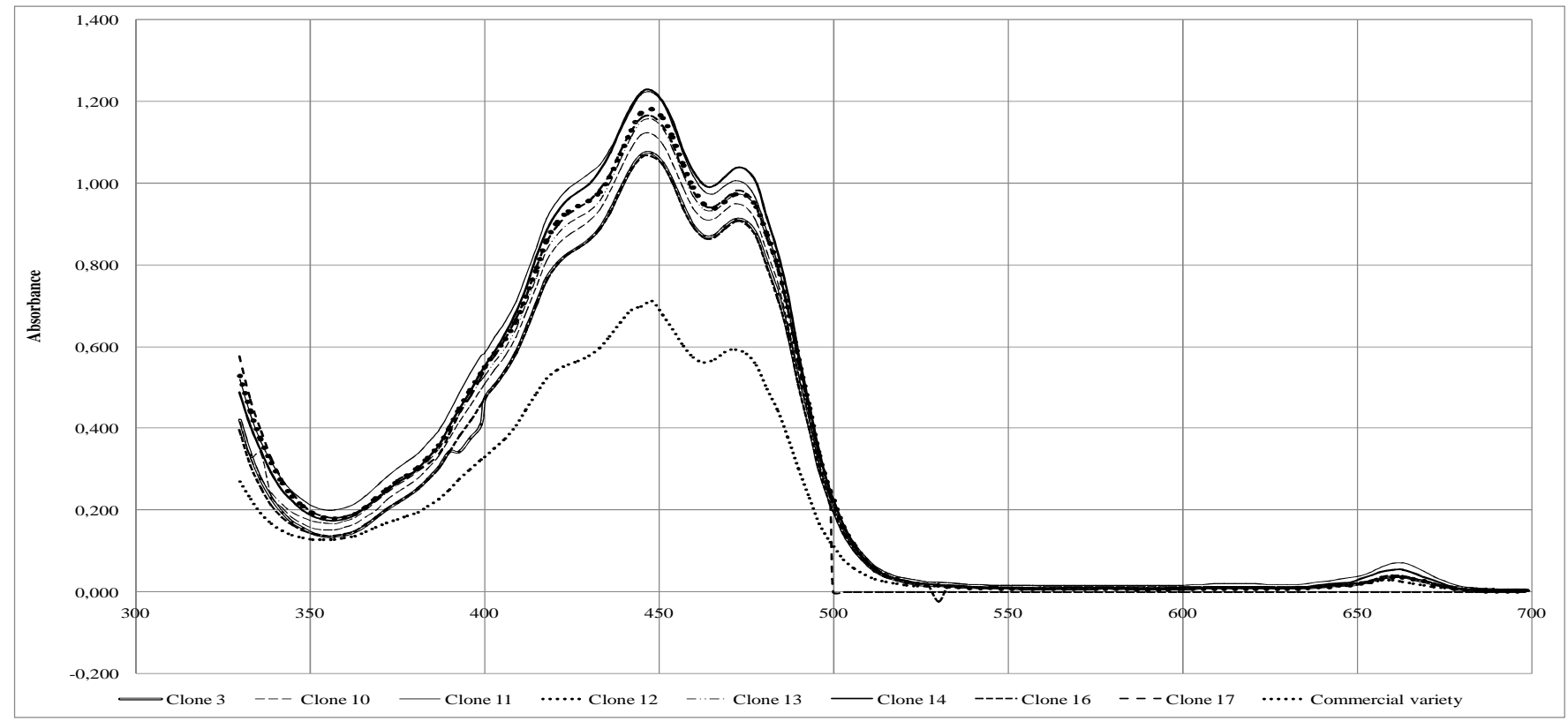

(B) 
Young and Britton (1990) stated that epoxide groups occur through photo-chemicals processes in plant tissues as protection mechanisms against high sun light irradiation; and Bungard et al. (1999) demonstrated that lutein is transformed in lutein-5, 6- epoxide for that reason. Therefore, the light affects carotenoid extraction from tubers through photo-chemical processes.

Due to the observed hypochromia, the spectral peaks obtained were close to the values reported by Britton et al. (2004) and Davies (1976). Consequently, the $\lambda_{\max }$ was displaced to a lower wavelength. Additionally, spectrophotometric and chromatographic analyses confirmed that pigments from promising clones and commercial variety of Criolla potato showed similar chemical structure due to the fact that $\alpha$ carotenoid is an isomer of the $\beta$-carotenoid and lutein is a dihydroxide derived from the $\alpha$-carotenoid (Rodriguez-Amaya and Kimura, 2004).

Selection and stability of extracted carotenoids. The results demonstrated that the Lambert-Beer law was verified, thus, the higher concentrations of carotenoid were due to $\alpha$-carotene. Clones 11, 12 and 14 were selected for their higher content of carotenoids at $1.3459,1.3018$ and $1.3525 \mu \mathrm{g} / \mathrm{g}$, respectively. Table 1 shows the effect of three different parameters on extracted $\alpha$-carotene from the above mentioned clones.

Table 1. Stability of carotenoids under different temperature, light and $\mathrm{pH}$

\begin{tabular}{c|c|c|c|c}
\hline \multirow{2}{*}{ Clones } & \multicolumn{4}{|c}{ Absorbance $\left(\boldsymbol{\lambda}_{\max }\right)$} \\
\cline { 2 - 5 } & Darkness & 50 and $70^{\circ} \mathrm{C}$ & Light & 1 and $13.5 \mathrm{pH}$ \\
\hline 11 & 1.222 & -- & 0.256 & -- \\
12 & 1.187 & -- & 0.170 & -- \\
14 & 1.227 & $1.227 ; 1.225$ & 0.185 & $0.511 ; 0.302$ \\
\hline
\end{tabular}

As per Table 1, carotenoids from clone 14 exhibited degradation in their color intensity caused for extreme $\mathrm{pH}$, which occurred due to the isomerization to cis/trans of the tetraterpenoids 
double bonds as shown by Melendez-Martinez et al. (2004). This instability showed absorbance readings of degraded samples to be lower than the original readings. Concerning temperature, carotenoids were stable because their absorbance results showed no color degradation of during 15 minutes at 50 or $70{ }^{\circ} \mathrm{C}$ heating. Melendez-Martinez et al. (2004) found that carotenoids maintain their stability under this temperature range; however the volume is reduced due to hexane evaporation. As to the effect of light, carotenoids showed low spectrophotometric readings caused by degradation in the light compared to high absorbance readings in dark storage. Light drives photochemical reactions due to the rupture of double bonds of tetraterpenoids generating low weight molecules, causing loss of color and biological function as provitamin A.

Utilization of extracted selected carotenoids. Each of the $\alpha$ carotenes extracted from three selected clones was added to a specific commercial yogurt. They displayed opaque colors (Table 2) in the white zone of spatial coordinates CIELAB with $L^{*} 48.66$ (luminosity) $a^{*}-1.65$ (color saturation between red and green) $b * 5.63$ (color tone between yellow and blue).

Table 2. Color readings with colorimeter Konica Minolta ${ }^{\circledR}$ Modelo CR-400

\begin{tabular}{ccccc}
\hline Samples & Triplicate & $\mathbf{L}^{*}$ & $\mathbf{a}^{*}$ & $\mathbf{b}^{*}$ \\
\hline \multirow{2}{*}{ Yogurt } & 1 & 51,84 & 0,23 & 1,07 \\
& 2 & 53,91 & $-0,01$ & 1,25 \\
& 3 & 54,66 & $-0,1$ & 1,15 \\
\hline Samples & Clones & $\mathbf{L}^{*}$ & $\mathbf{a}^{*}$ & $\mathbf{b}^{*}$ \\
\hline Yogurt + $\mathbf{\alpha}-$ & 11 & 46,55 & $-1,06$ & 4,74 \\
carotenoide & 12 & 47,85 & $-1,38$ & 5,30 \\
& 14 & 48,66 & $-1,65$ & 5,63 \\
\hline
\end{tabular}

The readings of the $L^{*}$ coordinate for the colored yogurt showed luminosity with tendency to opaque the yogurt with $\alpha$-carotene. Likewise, the $a^{*}$ coordinate presented low saturation since the readings had coordinates close to zero, namely, colors with lower intensity caused by the opaque yogurt. As for the $b^{*}$ 
coordinate showed the sample color with noticeable variation, between 1.07 and 5.63. The original yogurt, without any pigments, was white, while yogurt with $\alpha$-carotene tended to show a yellow zone of spatial coordinates.

Statistical analysis. Experimental spectrophotometric results analyzed by descriptive statistics showed little variation of their variances which proved that values of absorbance were dependable among repetitions. As for one way randomized ANOVA found significant differences $(p<0.05)$ among the amounts of carotenoids extracted from 15 promising clones and 1 commercial variety.

Tukey test $(p<0.05$ and $q=5.244)$ grouped three similar groups of carotenoids. Group I included 4, 6, 7 and 8 clones with similar amount of extracted lutein-5, 6-epoxide. Group II included 15, 5 and 2 clones showing the same amount of lutein-5, 6-epoxide, and of a-carotene from commercial variety. Group III included $16,3,10,13,17,12,11$ and 14 clones with the same amount of a-carotene. Tukey test confirmed the behavior of spectral curves of Figure 1 which presented the groups of spectral peaks according to statistical analysis.

\section{Conclusion}

The 15 promising clones and 1 commercial variety of Criolla potato (Solanum tuberosum Group Phureja) were grouped into two categories, one contained lutein-5, 6-epoxide, and the other contained $\alpha$-carotene. Clones 11, 12 and 14 showed the highest amount of carotenoids, as well as, best stability at temperatures of 50 and $70^{\circ} \mathrm{C}$ as well as in darkness. The results obtained in terms on methods and approaches appear to be useful for future industrial food production because these carotenoids can be used as a natural yellow pigment for a variety of products such as soap, flour, cheese, and so on. Moreover, carotenoids can be colored in ranges up to yellow of $L^{*} a^{*} b$ CIELAB coordinates.

\section{Acknowledgments}


The authors thank CORPOICA for supplying the promising potato clones and to Universidad de La Salle, for providing the laboratory facilities for conducting the experiments.

\section{References}

Biswas, A.K.; J. Sahoo; M.K. Chatli. 2011. A simple UV-Vis spectrophotometric method for determination of $\beta$-carotene content in raw carrot, sweet potato and supplemented chicken meat nuggets. Food Science and Technology. 44 (8): 1809-1813.

Britton, G.; S. Liaaen-Jensen; H.Pfander. 2004. Carotenoids Handbook. Basel: birkahuser.

http://books.google.com.co/books?id=If3KX07orYIC\&printsec=frontcov er\&dq=britton+carotenoids\&hl=es\&sa=X\&ei=wOTZT yMEoP28gT5qsz rBQ\&ved=0CDMQ6AEwAA\#v=onepage \& $q=$ britton\%20carotenoids \& $f=f$ alse 669 p. Consulta: Mayo, 2012

Bungard, R.; Ruvan, A.; Hibberd, J.; Press, M.; Horton, P.; Scholes, J. 1999. Unusual carotenoid composition and a new type of xanthophylls cycle in plants. Proceedings of the National Academy of Sciences of the USA J. 96 (3): 1135-1139.

Burgos, G.; E.Salas; W. Amoros; M.Auqui; L. Muñoa; M.Kimura; M. Bonierbale. 2009. Total and individual carotenoide profiles in Solanum phureja of cultivated potatoes: I. Concentrations and relationships as determined by spectrophotometry and HPLC. Food Composition and Analysis J. 22 (6): 503-508.

Cerón, M.S.; C.P. Álvarez; L. Prieto; C. Arango; J. Argüelles. 2012.( CHECK ; 2012 OR 2010?) Generación de variedades mejoradas de papa Criolla (Solanum phureja), con características morfoagronómicas, de cosecha, acondicionamiento y transformación, ideales para la exportación en el Departamento de Cundinamarca. Proyecto de investigación entre Corpoica-Universidad de La Salle financiado por el Ministerio de Agricultura y Desarrollo Rural, Colombia.

Corzo, P.; J.D. Moreno;B. Franco; L. Fierro. 2003. Manual de papa para productores. Corpoica. Ministerios de Agricultura y Desarrollo Rural. Colombia.

http://books.google.com.co/books?id=dhQxzRU9S0C \&printsec=frontco 
ver\&hl=es\&source=gbs ge summary $r \& c a d=0 \# v=0$ nepage \&q\&f=fals 93 p. Consulta: Marzo, 2012

Davies, B. 1976. Carotenoids in Goodwin TW. Chemistry and biochemistry of plant pigments. Academic Press, London. 38-165 p.

Galicia, R. M. 2009. Extracción de pigmentos carotenoides en jitomate (Lycopersicon esculentum Mill.) y su aplicación en sistemas alimentarios modelo. Tesis de doctorado, Universidad Autónoma Metropolitana, México.

ICBF. 2012. Tabla de composición de alimentos. Bienestar Familiar, Colombia.

http://alimentoscolombianos.icbf.gov.co/alimentos colombianos/consul ta alimento.asp Consulta: Febrero, 2012

Meléndez-Martínez, A. J.; I.M.Vicario; F.J. Heredia. 2004. Estabilidad de los carotenoides en los alimentos. Scielo. ALAN. 54 (2): 209-215 http://www.scielo.org.ve/scielo.php?pid=S0004-

06222004000200011\&script=sci arttext Consulta: Marzo, 2012

Martínez, A. 2003. Carotenoides. Universidad de Antioquia, Facultad de Química Farmacéutica, Medellín. http://farmacia.udea.edu.co/ ff/carotenoides2001.pdf 10 p. Consulta: Febrero, 2012

Muñoz-Delgado, J. A. 1985. Refrigeración y congelación de alimentos vegetales. Fundación española de la nutrición, Madrid.

Olmedilla, B.; F. Granado; I. Blanco. 2001. Carotenoides y salud humana. Fundación Española de la Nutrición, Madrid. 17 p.

Rodríguez, G. 2001. Extraction, isolation, and purification of carotenoids. Current protocols in food analytical chemistry. 2(1): 1-8.

Rodríguez-Amaya, D.; M. Kimura. 2004. HarvestPlus handbook for carotenoid analysis. Technical Monograph Series. International Food Policy Research Institute (IFPRI) and International Center for Tropical Agriculture (CIAT). Washington DC. 63 p. 
Santos-Soriano, J.; M.E. Zavaleta; M.A. Armella; M.L. Yañez; I. Guerrero. 2007. Caracterización parcial del pigmento rojo del fruto de la "jiotilla". Revista Mexicana de Ingeniería Química. 6 (1): 19-25.

Young, A.; G. Britton. 1990. Photobleaching in the unicellular green alga Dunaliella parva 19/9. Photosynth Res. 25: 129-136. 